\title{
Erken çocukluk eğitimi öğretmen ve yöneticilerinin Covid- 19 pandemi deneyimleri: Yorumlayıc fenomenolojik analiz
} Early childhood education teachers and administrators experices of Covid-19 pandemic: Interpretative phenomenological analysis

\author{
Nesrin Iş1koğlu ${ }^{1}$, Atiye Adak Özdemir ${ }^{2}$, Merve Altun ${ }^{3}$, Erinç Ergenekon ${ }^{4}$
}

\begin{abstract}
Makale Geçmişi
Geliş : 23 Aralık 2020

Düzeltme : 5 Temmuz 2021

Kabul : 10 Ekim 2021
\end{abstract}

\section{Makale Türü}

Araștrma Makalesi

\begin{abstract}
Öz: Bu araștırmanın amacı erken çocukluk eğitimi öğretmenlerinin ve yöneticilerinin COVID-19 pandemi dönemindeki uzaktan eğitim deneyimlerini ortaya çıkarmaktır. Araştırmanın katılımcıları 32 okulöncesi öğretmeni ve sekiz yöneticiden oluşturmaktadır. Araştırmada nitel araştırma yöntemlerinden fenomenolojik desen kullanılmıştır. Veriler yarı yapılandırılmış çevrim içi görüşme formu ve telefon görüşmesi ile elde edilmiş ve yorumlayıcı fenomenolojik analiz ile çözümlenmiştir. Bulgular pandemi algisı, bu süreçte öğretmen ve yönetici olmak ve uzaktan eğitim vizyonu adlı temalar çerçevesinde sunulmuştur. Bu çalışmadan elde edilen bulgulara göre, katılımcılar pandemiyi "rahatlama-aşırı kaygı" şeklinde birbiriyle yer değiştiren zıt duygular şeklinde deneyimlemişlerdir. Katıllımcı öğretmenlerin pandemi sürecinde uzaktan eğitimi çoğunlukla hazır planlar kullanarak yürüttükleri anlaşılmaktadır. Araştırma sonuçları bazı katılımcıların uzaktan eğitimin sürdürülebilirliği bağlamında örgün eğitime destek olarak kullanılması, uzaktan eğitim platformlarının erişim ve içerik açısından zenginleştirilmesi, öğretmenlerin teknoloji becerilerinin geliştirilmesi ve uzaktan eğitim yeterlikleri şeklinde üç farklı vizyon ortaya koyduklarını göstermektedir.
\end{abstract}

Anahtar Kelimeler: Pandemi, Erken çocuklukta uzaktan eğitim, Öğretmenler, Okul müdürleri
Article History

Received : 23 December 2020

Revised : 5 July 2021

Accepted : 10 October 2021

\section{Article Type}

Research Article

\begin{abstract}
This study aimed to examine the distance education experiences of early childhood education teachers and administrators during the COVID-19 pandemic period. The participants of the study consisted of 32 preschool teachers and eight school principals. A qualitative phenomenological design was used as a research method and the data was collected through online interview forms and semistructured phone interviews with the participants. Interpretative phenomenological analysis was used to analyze interview data. The findings were presented within the framework of the themes of pandemic perception, being a teacher and administrator in this process, and the vision of distance education. According to the findings from this study, the participants experienced the pandemic in the form of contrasting emotions replaced by "relaxation-excessive anxiety". The research results showed that some of the participants put forward three different visions in the context of the sustainability of distance education: using it as support for formal education, enriching distance education platforms in terms of access and content, improving teachers' technology and distance education competencies.
\end{abstract}

Keywords: Pandemic, Distance education in early childhood, Teachers, School principals

\footnotetext{
${ }^{1}$ Prof. Dr. Pamukkale Üniversitesi, Eğitim Fakültesi, Okulöncesi Eğitimi ABD, Denizli. nisikoglu@pau.edu.tr, https://orcid.org/0000-0001-7010$302 \mathrm{X}$

${ }_{2}^{2}$ Doç. Dr. Öğr. Üyesi, Pamukkale Üniversitesi, Eğitim Fakültesi, Okulöncesi Eğitimi ABD, Denizli. aadak@pau.edu.tr https://orcid.org/0000-0002-9481-8051

3 Ögrr. Gör., Pamukkale Üniversitesi, Denizli. e-posta: eergenekon@pau.edu.tr, http://orcid.org/0000-0002-9683-7600

${ }^{4}$ Öğr. Gör., Mehmet Akif Ersoy Üniversitesi, e-posta: maltun@mehmetakif.edu.tr, http://orcid.org/0000-0003-2866-8646
} 


\section{SUMMARY}

\section{Introduction}

Due to COVID-19 pandemia some arrangements were made in social life in order to prevent the spread of the disease. One of the arrangements was the closure of schools. However, countries tended to continue their education programs remotely in the spring semester of 2019-2020 in order to maintain education. In the early childhood period, children often need helps to use computers, tablets and the internet (Iş1koğlu Erdoğan, 2019; Kim, 2020; Manches, vd., 2017), this required parents to directly accompany the education process of the children in the distance education process. This situation is likely to cause the distance education process in early childhood to be experienced differently by both teachers and school principals and families from other educational levels. Therefore it is important to examine the distance education experiences of early childhood teachers and principals. Again, research dealt with distance education and pandemic in early childhood period is very limited. For this reason, the research contribute empirical findings to the related literature. The aim of the study is to examine the experiences of early childhood education teachers and school principals in during the pandemic.

\section{Method}

This study utilized a qualitative, phenomenological design. The participants of the study consist of 32 teachers and eight school principals who were selected based on the criteria of actively working in the 20192020 academic year. The participant teachers work experiences ranged between three and 24 years and they worked with 3-6 years old children. The data were obtained through the interview form and semi-structured in-depth individual interviews. The interview form consists of 16 open-ended questions about their experiences of distance education. Later with the volunteered participants in-depth video-chat interviews were conducted to revealed their experiences. These interviews lasted approximately 20-40 minutes were recorded.

The interpretative phenomenological analysis (SFA) method was used to analyze interviews. The principles explained in Larkin et al (2006) were taken into account during the data analysis. Interview forms and transcripts were transcribed. The first two authors read the whole data several times and took notes on the margins. Later, individually coded data and reconciled the differences among the codes and categories. According to Huberman and Miles (1994), intercoder reliability was calculated as $85 \%$. In the last stage, interpretative explanations of the themes were written and quotations reflecting these comments were selected.

\section{Results}

As a result of the interpretive phenomenological analysis, four basic themes emerged. These were explained as (1) "perception of the pandemic", (2) "being a teacher" (3) "being a school principal" and (4) " vision of distance education". Participant early childhood education administrators and teachers stated that they 
obtained basic information about the concept of Covid-19 through the media. Through out the pandemic participants conceptualized two different tendencies that changed over time as "relaxing" and "excessive worrying". Results also revealed the important changes in teachers' behaviors about educational activities and in their relations with administrators, children and families. They described these changes as difficulties. Additionally, the administrators also implied that they had both difficulties and advantages they encountered during pandemic.

\section{Conclusion and Discussion}

The research revealed three important conclusions. Firstly, the participants defined COVID-19 scientifically and explained their experiences regarding pandemic by highlighting their emotional states such as "invisible enemy, insidious, test, a lesson to humanity." They experienced the pandemic in the form of contrasting emotions that were replaced by "relief-excessive anxiety". The participants had to adapt to various changes in the individual and public sphere during the pandemic. This situation attributed the potential to affect individuals psychologically to the pandemic (Aşkın, Bozkurt ve Zeybek, 2020). The secondly teachers and administrators decoded their teaching experiences with their knowledge and skills that relevant for formal education. On the other hand, they highlighted that the new communication style focused on social media and audio / video communication technologies experienced with families during the distance education. The via communication with the children were described as difficult by the participant teachers and interacting with children created several obstacles to conduct, deliever and evaluate educational activities. The teachers perceived the administrators as "transmitting the correspondence" in the process and pointed out that they could not get enough support from them to teaching distance activities. This situation caused the participant teachers to took on the role of transmitting the daily plan files to the parents and expecting them to implemente and teach their children required knowledge and skills. Other studies about pandemic are in line with the findings of this study (Cheng, 2020)., The participant principals mentioned the positive effects of pandemic on their private lives and professional development. Moreover, they mentioned about negative effects of pandemic on their professional positions and described these effects as as "loneliness and loss of authority". In addition, some of the participant principals complained that several teachers perceived distance education as "a holiday" and they had problems in reaching these teachers. Thirdly the research showed that the participants mainly expressed opposition to distance education in early childhood. They has three different visions related to the distance education (1)using distance education as a support for formal education,(2) enriching distance education platforms in terms of free access and rich content, and (3) improving early childhood teachers' knowledge and competencies about technology and distance education. 


\section{GİRİŞ}

Etki potansiyeli, zamanı ve yeri önceden kestirilemeyen bireylerin rutinlerini kesintiye uğratma veya durdurma potansiyeli taşıyan olay ve durumlar afet olarak tanımlanmaktadır (Ergünay, 2009; Karabulut ve Bekler, 2019). Afetler sosyal, politik ve ekonomik etkilerin yanı sıra eğitimin kesintiye uğraması şeklinde olumsuz sonuçlara da yol açabilmektedirler (Szente, 2016). Yaklaşık iki yıldır COVID-19 (yeni koronavirüs hastalığı) olarak tanımlanan biyolojik kaynaklı afet (T.C. Sağlık Bakanlığ1 Halk Sağlığ1 Genel Müdürlüğ̈̈, 2020) yaşanmakta ve hayatın her alanında çeşitli sonuçlara yol açmaktadır. Hastalığın kişiler arası etkileşimle bulaşma riski taşıması sokağa çıkma yasakları, eğitim kurumlarının, iş ve eğlence yerlerinin kapatılması gibi halk sağlığını korumaya dönük önlemlerin alınmasını gerekli kılmıştır. Eğitim kurumlarında yüz yüze eğitime ara verilerek 20192020 öğretim yılının uzaktan eğitim aracılığı ile tamamlanması kararı (Milli Eğitim Bakanlığı, 2020) ülkemizde bu kapsamda alınan önlemlerden biridir.

Bu kararla birlikte ülkemizde anasınıfları, anaokulları, kreşler gibi erken çocukluk eğitim hizmeti sunan birim ve kurumlar da uzaktan eğitim uygulamasına geçmiştir. Bu uygulama ile yöneticilerinin, öğretmenlerinin, kuruma devam eden çocukların ve ailelerinin eğitim deneyimleri ve günlük rutinleri değişmiştir. Çocuklar açısından bakıldığında uzaktan eğitimle birlikte evde kalan çocukların arkadaşları ve öğretmenleri ile iletişimleri ekran veya mobil iletişim cihazlanı ile sınırlanmıştır. Tam gün ve yarım günlük eğitim etkinliklerinden oluşan eğitim programın yerini öğretmen tarafindan ailelere iletilen eğitim plan ve etkinlik önerileri almıştır. Çocukların hareket ve oyun firsatları ev ve ailelerin sahip olduğu olanaklar ile sınırlanmıştır. Çocukların okula gidememeleri, sokağa çıkamamaları ve arkadaşlarıyla birlikte olamamaları kaygı ve endişenin yanı sıra uzun vadede gelişimsel problemlere yol açabilmektedir (OMEP, 2020; Yoshikawa, Wuermli, Britto, Dreyer, Leckman, Lye, Ponguta, Richter ve Stein, 2020). Başta bilişsel gelişim olmak üzere bedensel, sosyal ve duygusal alanlarda hızlı bir gelişim sürecinde olan çocukların bu dönemde nitelikli eğitim fırsatlarından mahrum kalmaları uzun ve kısa vadeli gelişimsel riskler oluşturabilmektedir (Yoshikawa, vd., 2020). Bununla birlikte pandemi gibi insan hayatını tehdit eden durumlarda duyuşsal gereksinimler akademik gereksinimlere göre daha ön plandadır (Bozkurt ve Sharma, 2020). $\mathrm{Bu}$ süreçte ailede yaşanan iş kayıpları, ekonomik zorluklar ve stres çocukların iyi oluşlarını etkileyebilmektedir (Prime, vd., 2020, 631). Benzer şekilde araştırmalar afet deneyimlerinin çocuklarda korku, panik, üzüntü (Hassan, Singh ve Sekar, 2018), davranış problemleri (Cupit Swenson, Saylor, Powell ve Belter, 1996) geri çekilme ve öz düzenleme problemleri (Petriwskyj, 2013) gibi kısa ve uzun dönemli etkiler yarattığını göstermektedir. COVID-19 pandemisi kapsamında yapılmış olan araştırma bulguları çocuklarda öfke nöbetleri (Alisinanoğlu, Türksoy ve 
Karabulut, 2020) korku ve kaygılarında artış, uyku düzenlerinde soruna işaret etmektedir (Tarkoçin, Alagöz ve Boğa, 2020).

Aileler açısından incelendiğinde COVID-19 pandemi sürecinde anne ve babalar hastalık bulaşma riski ve iş koşullarında değişiklik gibi sorunlarla yüzleşmek durumunda kalmışlar ve bu durum onları duygusal açıdan olumsuz etkilemiştir (Göl-Güven, Alvan, Erbil, Özgünlü, Şeker, ve Uzunkök, 2020). Pandemi sürecinde aileler kendi mesleklerini, ev işlerini, çocuk bakımını bir arada yürütmüşlerdir (Demir Öztürk, Kuru ve Demir Yıldız, 2020; Yılmaz, Mutlu, Güner ve Doğanay, 2020). Özellikle erken çocukluk dönemindeki çocukların ebeveynleri bu süreçte doğrudan öğretici rolünü üstlenmişler ve evi okul olarak tasarlamak durumunda kalmışlardır. Bu durum aileleri aşırı bir yük altına sokmuştur (Bozkurt vd., 2020)

Benzer şekilde erken çocukluk eğitimi öğretmen ve yöneticileri aile rutinleri ile birlikte iş yaşamlarını evden yürütmek zorunda kalmıslardır. Pandemi süreci öğretmenlerin performansını olumsuz etkilemiş ve öğrencilere akademik ve duygusal destek sağlamalarını zorlaştırmıştır (Seyle, Widyatmoko ve Silver, 2013; Y1lmaz, Mutlu, Güner ve Doğanay, 2020; Bozkurt vd., 2020).

\section{COVID-19 Pandemi Sürecinde Uzaktan Eğitim}

Uzaktan eğitim iletişim teknolojileri aracıllğ̆1 ile yürütülebilen eğitim olarak tanımlanmakta (Al ve Madran, 2004) ve 1800 'lü yıllardan beri dünya genelinde geleneksel eğitimin alternatifi olarak kabul görmektedir (Stock McIsaac, 2020). Mektupla başlayan uzaktan eğitim süreci, radyo-televizyonla devam etmiş, günümüzde ise bilişim tabanlı (internet-web) teknolojilerle anılır olmuştur (Bozkurt, 2017). E-öğrenme olarak da adlandırılan uzaktan eğitim asenkron eğitim, web veya CD-ROM, canlı sanal sınıf, canlı ses/uygulama/video paylaşımı gibi modeller şeklinde yürütülebilmektedir (Balaban, 2012).

Genel olarak bakıldığında tüm dünyanın COVID-19 pandemi sürecinde değişen koşullarda eğitimi sürdürme konusunda hazırlıksız olduğu söylenebilir (Bozkurt ve Sharma, 2020). Ancak dünyada ve Türkiye'de eğitimi sürdürebilmek adına çeşitli uygulamalar gerçekleştirilmiştir. Eğitimi çevrim içi ortamda sürdürmek kullanılan yaygın seçeneklerden biri olmuştur. Bununla birlikte çok sayıda ülkeden elde edilen verilerle gerçekleştirilen bir araştırma internet erişimindeki sınırlılıkların çevrim içi eğitime katılımı sınırlandırdığını ortaya koymakta ve eğitime devam edemeyen çocuklar için farklı seçeneklerin işe koşulması gerektiğine vurgu yapmaktadır (Reimes ve Schleicher, 2020). Ayrıca COVID-19 pandemi döneminde deneysel araştırmalardan elde edilen bulgular uzaktan eğitimin bu yaş gurubu çocuklarda yüz yüze eğitime alternatif olamayacağını ve çocukların çeşitli alanlardaki becerilerini desteklemede yeterli etkiyi yaratmadığını ortaya koymaktadır (Aral, Fındık, Karataş, Güneş ve Kadan, 2020). 
Ülkemizde Milli Eğitim Bakanlı̆̆ 23 Mart 2020 tarihinden itibaren uzaktan eğitim sürecinde öğretmen ve öğrencileri ulusal dijital eğitim platformu olan Eğitim Bilişim Ağg’na (EBA) (www.eba.gov.tr) ve televizyonda EBA TV kanallarına yönlendirmiştir. İnteraktif içerikleri de barındıran EBA'da öğretmenler diğer kullanıcılarla ses, video ve dokümanları paylaşabilmekte ve canlı dersler yürütebilmektedir (EBA, 2020). EBA'da yer alan okul öncesi eğitim portalı, etkinlik havuzu, çizgi film, oyun gibi içeriklerden oluşmaktadır. Aynı zamanda öğretmenler çocuklarla dosya, etkinlik, mesajlarını paylaşabilmekte ve çocukların bu etkinliklere katılımını ve paylaşımlarını izleyebilmektedir (EBA, 2020). Farklı ülkelerdeki erken çocukluk eğitim kurumlarının uzaktan eğitim sürecindeki uygulamaları çeşitlilik göstermektedir. Bazı Avrupa ülkelerinde bu süreçte ulusal televizyon ve çevirim içi içerikler birlikte kullanılarak uzaktan eğitim yürütülürken (Tokić ve Vukašinović, 2020) erken çocukluk eğitiminin bir hak olarak görüldüğü ülkelerde çocukların kurumda eğitime devam etmesi anlayışı benimsenmiştir. Bazı ülkelerde ise kurumlar kapatılarak eğitim belirli saatlerde yayın yapılan sanal sınıflar aracilığı ile devam ettirilmiştir (Samuelsson, Wagner ve Ødegaard, 2020). Erken çocukluk eğitiminde farklı bir anlayışı benimseyen Regio Emilia okullarında bu süreçte öğretmenler tarafından okunan hikayeler video-ses kaydı olarak çocuklara ulaştırılmış ve okul web sitesinde yayınlanmıştır (Reggio Children, 2021). Bu uygulamanın çocukların akademik bir içeriğge ulaşmasına aracılık etmenin yanı sıra öğretmeninin sesi aracilığı ile sosyal duygusal destek sağlaması açısından erken çocukluk döneminde etkili bir uygulama olduğu söylenebilir.

COVID-19 pandemi sürecinde önceden planlanmayan bir biçimde okulların kapanması eğitim ve iletişimde teknoloji kullanımını zorunlu kılmıştır (World Bank Group, 2020). Öte yandan, erken çocukluk eğitimi öğretmen ve yöneticilerinin uzaktan eğitimle ilgili bilgi, beceri ve deneyimlerinin sınırlı olduğu ve teknoloji entegrasyonuna karşı oldukları vurgulanmaktadır (Konca vd., 2016; Mertala, 2019; Yurt vd., 2011). Öğretmen yetiştirme programlarında ve hizmet içi eğitimlerde uzaktan eğitimle ilgili konulara sıklıkla yer verilmediği ve COVID-19 pandemi sürecinde ise öğretmenlere uzaktan eğitim konusunda sınırlı oranda destek sağlandığı vurgulanmaktadır (Stock McIsaac, 2020). Öğretmenler pandemi sürecinde öğrenci katılımı ve motivasyonunu sağlama, öğrencilere uzaktan destek sağlama, kırsal kesimde ve dezavantajlı bölgelerdeki öğrencilerle iletişim kurma konularında sorunlar yaşamışlardır (Yılmaz, Mutlu, Güner ve Doğanay, 2020). Farklı ülkelerdeki öğretmenlerin pandemi sürecinde en çok teknolojik altyapıya ulaşılması, öğrencilerin ruhsal sağlığının ele alınması, dijital olan ve olmayan aktivitelerin doğru bir şekilde dengelenmesi, teknolojik altyapının yönetilmesi ve değişikliklere uyum sağlanması sorunlarına vurgu yaptıkları anlaşılmaktadır (OECD, 2020). 
Erken çocukluk döneminde çocukların dijital araç kullanımları yaygınlaşmaktadır. Ancak çocukların gelişimsel özellikleri bilgisayar, tablet, internet ortamlarındaki eğitim uygulamalarına yardımsız olarak katılımlarının önünde engel oluşturabilmektedir (Işskoğlu Erdoğan, 2019; Kim, 2020; Manches, vd., 2017). Bu durum uzaktan eğitim sürecinde ebeveynlerin aktif katılımını gerektirmekte, öğretmen ve yöneticiler açısından da uzaktan eğitimin diğer eğitim kademelerinden farklı yaşanmasına yol açmaktadır. Erken çocukluk eğitiminde yönetici ve öğretmenlerin pandemi sürecindeki deneyimlerini konu alan araştırmalar sınırlı sayıdadır ve bu bağlamda araştırmanın alan yazına katkı sağlaması bakımından önemli olacağı düşünülmektedir. Özellikle öğretmen ve yöneticilerin pandemi sürecinde yaşantılarının birlikte ele alınması ve sürecin farklı personeller tarafından nasıl deneyimlendiğinin ortaya koyulması eğitim öğretim süreçlerinin daha etkili bir şekilde planlanması açısından yararlı olacaktır. Ayrıca, erken çocukluk eğitiminde COVID-19 pandemisinde uzaktan eğitim sürecinin incelenmesi, pandeminin devam etmesi durumunda yapılacak olan uzaktan eğitimin daha etkili ve çocukların gelişimlerini destekleyici olması yönünde katkı sağlayacaktır. Araştırmanın gelecekte yapılacak uzaktan eğitim planlamalarına rehberlik edeceği ve çözüm önerileri sunulmasına katk1 sağlayacağı düşünülmektedir. Bu doğrultuda araştırmanın amacı erken çocukluk eğitimi öğretmenleri ve yöneticilerinin pandemi sürecindeki deneyimlerinin incelenmesidir.

\section{YÖNTEM}

\section{Araştırmanın Deseni}

Erken çocukluk eğitimi öğretmen ve yöneticilerinin COVID-19 Pandemi sürecinde yaşadıkları deneyimleri inceleyen bu araştırmada fenomenoloji deseni seçilmiştir. Bu desen bireylerin belirli olayları ve olguları nasıl algıladıklarını ve anlamlandırdıklarını belirlemek için kullanılır (Creswell, Hanson, Clark Plano, ve Morales, 2007). Bu araştırmada erken çocukluk eğitiminde görev yapan öğretmenlerin ve yöneticilerin pandemi sürecinde yaşadıkları eğitim deneyimlerini anlamaya odaklanılmıştır. Fenomenoloji katılımcıların kişisel deneyimlerini bağlama göre farklı anlamlandırdıklarını ve onların bakış açısından, deneyimlerinin nasıl bir şey olduğunu anlamaya çalışmakla ilgilenir (Smith, Flowers, Larkin, 2009). Erken çocukluk eğitim programının oyun ve gelişim temelli oluşu pandemi sürecinin diğer eğitim kademelerinden farklı deneyimleneceğini düşündürmektedir.

\section{Çalışma Grubu}

Katılımcılar belirlenirken ölçüt örnekleme tekniğine dayalı olarak okul öncesi öğretmeni ve yöneticisi unvanına sahip olma ve 2019-2020 eğitim öğretim yllında aktif olarak görevde bulunma 
ölçütleri oluşturulmuştur (Patton, 2014; Yıldırım ve Şimşek, 2013). Bu kriterleri taşıyan katılımcılara ulaşmak amacıyla, araştırmacılar Denizli ilinde bağlantılarının olduğu erken çocukluk eğitimi yöneticileri ve öğretmenlerini telefonla arayarak çalışmanın amacını açıklamış ve katılmaları için davet etmişlerdir. Bu süreçte 8 yönetici ve 40 öğretmen aranmış ve görüşme formlarının yer aldığ1 Google survey linki aday katılımcılarla paylaşılmıştır. Çalışmanın verileri ülkemizde yüz yüze eğitime ara verildiği ve uzaktan eğitime ilişkin ilk deneyimlerin yaşandığı Mayıs 2020'de toplanmaya başlamış ve iki aylık süreçte Haziran sonuna kadar tamamlanmıştır. Araştırmaya katılmaya gönüllü olan, görüşme formunda bulunan soruları yanıtlayan ve onam formunu dolduran 32 öğretmen ve 8 yönetici çalışma grubunu oluşturmuştur.

Çalışmaya katılan öğretmenlerin tamamı kadın iken yöneticilerin 2'si erkek 6'sı ise kadındır. Çalışma grubundaki öğretmenlerin hizmet süreleri 3 ile 24 yıl arasında değişmekte ve 3-6 yaş gruplarında öğretmenlik yapmaktadırlar. Öğretmenlerin 15’i anaokulunda, 17'si ise anasınıfında görev yapmaktadır. Yöneticiler 3 ile 10 yıl yöneticilik deneyimine sahiptir ve bulundukları okullarda en az 6 en çok 12 öğretmenle çalışmaktadırlar.

\section{Veri Toplama Araçları ve Süreci}

Araştırmanın verileri görüşme formu, yarı-yapılandırılmış bireysel görüşmeler ile elde edilmiştir. Öncelikle yönetici ve öğretmenlere yönelik 16 adet açık uçlu sorudan oluşan görüşme formu oluşturulmuştur. Görüşme formu erken çocukluk eğitimi alanında görev yapan dört akademisyen tarafından incelenmiş, uzman görüşleri alınmış ve bu doğrultuda sorulara son şekli verilmiştir. Görüssme formunda genel olarak COVID-19 pandemisinin ne anlama geldiği, pandemide katılımcıların neler hissettikleri, eğitim faaliyetlerini nasıl gerçekleştirdikleri ve geleceğe yönelik düşünce ve planlarını belirlemeye yönelik sorular bulunmaktadır. Görüşme formunun sonunda katılımcılara bireysel görüşmeye gönüllü olup olmadıkları sorulmuş ve gönüllü olanların telefon numaralarını paylaşmaları istenmiştir. Bu sürecin sonunda gönüllü olan 4 yönetici ve 12 öğretmenle sesli/görüntülü iletişim araçları ile bireysel görüşmeler gerçekleştirilmiştir. Yarı yapılandırılmış bireysel görüşmelerde katılımcılara deneyimlerini detaylı bir şekilde açılamaları, örnekler vermeleri ve görüşme formunda verdikleri cevapları netleştirmelerine yönelik sorular sorulmuştur. Bireysel görüşmeler 20 ila 40 dakika arasında sürmüş ve kayıt altına alınmıştır. Bulgular kısmında katılımcılardan doğrudan alıntıların sunumunda isim yerine kodlar kullanılarak katılımcıların kişisel bilgilerinin gizliliği sağlanmıştır. Ayrıca bu araştırma, Pamukkale Üniversitesi, Sosyal ve Beşeri Bilimler Araştırma ve Yayın Etiği Kurulu"nun 26/08/2020-E.50718 tarih ve sayılı izni ile uygun bulunmuştur. 


\section{Verilerin Analizi}

Araştırmanın verileri yorumlayıcı fenomenolojik analiz yöntemi (YFA) yoluyla çözümlenmiştir. Yorumlayıcı fenomenolojik analiz katılımcıların olguyu nasıl algiladıklarına ve deneyimlediklerine odaklanır. YFA'nın amacı olgunun sıklığını ölçmek yerine; anlamların içeriğini ve karmaşıklığını anlamaya çalısmaktır (Smith ve Osborn, 2004). Bu bağlamda bireylerin sesini duyurmak ve mantıklarını anlamak analizin temel amacıdır (Larkin, Watts ve Clifton, 2006). Verilerin analizinde Larkin ve ark (2006)'da açıklanan ilkelere göre (1) “Katılımcılar pandemiyi nasıl algıladılar ve yaşadılar?" (2) "Pandemi sürecinde yaşananların öğretmen ve yönetici olarak anlamları nelerdir?" (3) "Uzaktan eğitim olgusu ile ilgili sonuçlar ve çıkarımlar nelerdir?” temel analiz çerçevesi olarak ilk iki yazar tarafindan tartışlarak belirlenmiştir. Bu çerçeveye göre görüşme formları, görüşme transkriptleri ve örnek etkinlik dokümanları yazıya aktarılmış, birkaç kez araştırmacılar tarafindan okunmuş ve sayfa kenarlarına notlar alınmıştır. Araştırmacılar bu notları karşılaştırarak kodları ve bu kodlar arasındaki bağlantıları kurarak temaları belirlemişlerdir. Daha sonra iki araştırmacı bireysel olarak bir öğretmen, bir yöneticiye ait veriyi kodlamışlardır. Huberman ve Miles (1994) göre kodlayıcılar arası uyum oranı \%85 olarak hesaplanmıştır. Son aşamada, temaların yorumlayıcı açıklamaları yazılmış ve bu yorumları yansıtan alıntılar seçilmiştir.

Araştırmanın inandırıcılığını ve aktarılabilirliğini sağlamak amacıyla veri çeşitlemesi, derinlik odaklı veri toplama, ayrıntılı betimleme, katılımcı teyidi, kodlayıcılar arası uyum oranı hesaplaması ve uzman görüşü teknikleri kullanılmıştır (Creswell, 1998; Yıldırım ve Şimşek, 2013). Veri çeşitlemesi için görüşme ve dokümanlar birlikte kullanılmış, yarı yapılandırılımış görüşmelerle derinlik odaklı veriler elde edilmiştir. Analizler sonucunda elde edilen bulgular seçilen bir yönetici ve öğretmene okutularak katılımcı teyidi elde edilmiştir. Veri analizinde kodlayıcılar arası uyum hesaplanmıss ve görüssme sorularının uygunluğu uzman görüşü alınarak saptanmıştır. Ayrıca, araştırmacılar veri toplama sürecinde öğretmen ve yöneticilerin deneyimlerine dair görüş bildirmemeye ve onları etkilememeye özen göstererek tarafsız araştırmacı rolü üstlenmişlerdir (Stake, 1995).

\section{BULGULAR}

Yorumlayıcı fenomenolojik analiz sonucunda dört temel tema ortaya çıkmıştır. Bunlar (1) “pandemi”, (2) "öğretmen olmak" (3) “yönetici olmak" ve (4) "uzaktan eğitim vizyonu” olarak açıklanmıştır. 


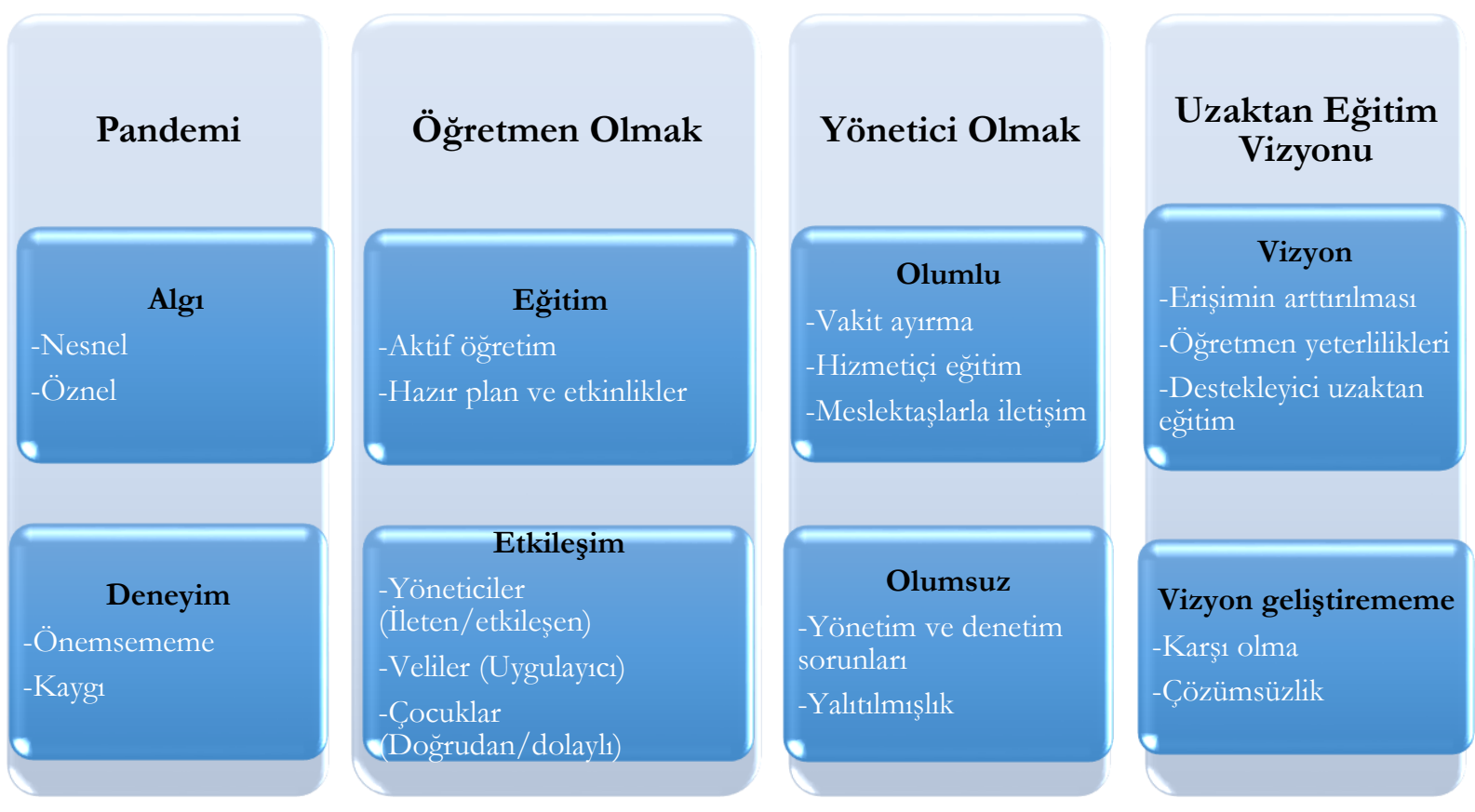

Şekil 1. Erken çocukluk eğitimi öğretmen ve yöneticilerinin Covid-19 pandemi deneyimleri

\section{Pandemi algisi}

Çalışmaya katılan erken çocukluk eğitimi yönetici ve öğretmenleri salgın hastalık kavramı ve hastalı̆̆ın özellikleri ile ilgili temel bilgileri medya aracıllğ̆ ile edindiklerini ifade etmişlerdir. Tüm katılımcılar COVID-19'u damlacıkla bulaşan bir virüsten kaynaklanan salgın hastalık olarak tanımlamışlardır. Bu çalışmadaki katılımcıların COVID-19'u tanımlamada "virüs" "hastalık" "bulaşıcı” gibi nesnel ögelerin yanı sıra günlük yaşamları, deneyimleri ve algıları temelinde "sinsi," “yapay”, " laboratuvarda üretilmiş”, "görülmeyen düşman”, “imtihan”, "ket vuran bir şey” ve “insanlığa verilen ders” gibi öznel yargılara da yer verdikleri anlaşılmaktadır. Yönetici 7 "COVID19 pandemisi, tüm insanlĭga verilmis bir derstir. Temiə̨lik ve bijyenin ne kadar önemli olduğunu anladık bu süreçte" ifadesiyle pandemi ile ilgili öznel algısını ortaya koymuştur.

Katılımcıların pandemiyi genel olarak zaman içerisinde birbiriyle yer değiştiren iki eğilim "önemsememe/rahatlama" ve "aşırı kaygılanma" şeklinde deneyimledikleri anlaşılmaktadır. Katılımcılardan bazılarının kavramla ilk karşılaştıklarında zihinlerinde anlamlandıramadıkları, kendilerine ulaşamayacak kadar uzakta olduğu, kısa sürede tedavisinin bulunacağı gibi algılarla önemsemedikleri ancak medyanın gündeminde kalma süresi, ülkemizde vaka tespiti yapılması ve yasal önlemlerle birlikte aşırı kaygıllanma eğilimi sergiledikleri anlaşılmaktadır. Örneğin Yönetici 2 ve Öğretmen 1 sırasıyla aşağıdaki ifadeleriyle pandemi deneyimini açıklamıştır: 


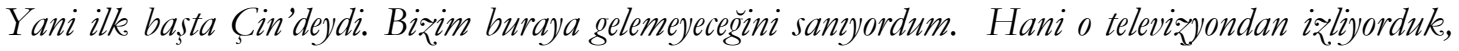
ama bižim için uz̧aktaydı. Bir nevi filmin fragmanlar gibi. Böyle ǚülï̈orduk, biz̨im buraya geleceğini düşünmüyorduk. Tabi gelince işin ciddiyetinin farkena vardık.

Aģıkçası önce çok faそ̧la kaygılanmadım dünyann farkh yerlerinde vardı. SARS gibi kısa bir sürede hallolabileceğini düs̆̈̈ndüm ama ölüm oranlarnm çok olması, hastalğgn tedavisinin bulunma sürecinin uzamasi sikint, korku, kaygi duygumu artırdi...

Bazı katılımcılar başlangıçta pandemi ile ilgili haberlerin medyada yoğun bir biçimde yer alması nedeniyle "panik", “endişe”, "tedirginlik", "korku” duygularını yoğun olarak yaşadıklarını belirtirken, süreç uzadıkça durumu yaşamlarının bir parçası olarak kabul etme eğilimi göstermişlerdir. Yönetici 5’in yanıtları aşırı kaygılanma eğiliminin önemsememe/rahatlama eğilimi ile yer değiştirmesini örneklendirmektedir: "Her gün ateşs ölçümü yaptım. Her birey gibi bende virüs tedirginlik oluşturdu. Şu an ise herkesin bu süreci yaşayacağın ve bir șekilde virüsle yaşamaya alışacağımıæ? düşünüyorum.” Şeklindeki ifadesi katılımcıların pandemi ile ilgili eğilimlerindeki medya faktörünü ortaya koymaktadır.

\section{Pandemi sürecinde öğretmen olmak}

Erken çocukluk eğitimcileri pandemi nedeniyle planlanmayan bir biçimde uzaktan eğitim sürecine dahil olmuşlar ve örgün eğitimdeki öğretmen- okul -öğrenci etkileşimleri ve öğretmenlerin rolleri bu süreçte değişmiştir. Bu çalışmanın bulguları öğretmenlerin uzaktan eğitim sürecinde eğitim öğretim etkinliklerine ilişkin davranışlarında ve yöneticilerle, çocuklarla ve ailelerle ilişkilerindeki değişiklikleri ortaya koymuştur. Uzaktan eğitim sürecindeki deneyimler, öğretmenlerin mesleklerini etkili bir biçimde gerçekleştirmesini zorlaştırmıştır. Tüm öğretmenler uzaktan eğitimde öğretmen olmay1 örgün eğitimde öğretmen olmaya göre “zor” olarak betimlemiştir. Öğretmen 26 "Ögrrencilerime bu şekilde yetemediğimiz̨i ve zaman geçtikçe ilginin düsmesine çok ürällüm. Yür yǚre eğitimden daha zordu.” Öğretmen 29 ise "Zordu. Okul Öncesi Öğretmeni olarak çocuklarla iç içe olmaya alışkın olduğum için bu süreç zor oldu” şeklinde ifade etmiştir. Öğretmenler bu söylemlerle örgün eğitimde benimsedikleri öğretmen rolleri ile uzaktan eğitim sürecinde öğretmenlik yapmanın zorluğunu dile getirmiştir. Öğretmen 19 ise "Dijital ögretmen olduk hiç hoşuma gitmedi” ifadesiyle uzaktan eğitim sürecindeki rolünden duyduğu hoşnutsuzluğu açıkça belirtmiştir.

Ayrıca bu çalışmanın bulguları öğretmenlerin pandemi sürecinde "aktif ögrretim” ve "hažr plan ve etkinlikler üzerinden ögretim” olarak adlandırılan iki temel davranışı benimsedikleri saptanmıştır. Sınırlı sayıda öğretmenin “aktif öğretimi” benimsediği ve eğitim etkinliklerini evde kendileri uygulayarak eğitim videoları hazırladıkları, bu videoları WhatsApp veya YouTube aracıllğı ile çocuklara ulaştırdıkları, EBA, ZOOM, Adobe Connect gibi uzaktan eğitim platformlarını kullanarak 
etkinliklerini canlı yayınlar aracıllğıyla gerçekleştirdikleri saptanmıştır. Aktif öğretim davranışlarını benimseyen Öğretmen 1 aşağıdaki ifadelerle durumu açıklamışır.

Ama bu süreçte en basit bir konuyu bile velinin anlatabileceği düzeyde aktarmak çok zordu,... Seviyeyi

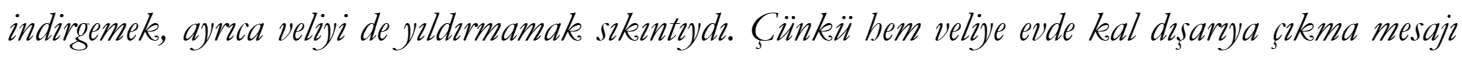
veriyorsunuг, hem de janjanh faaliyetler yollamak bana saçma geldi. Mümkün olduğunca evde yapabilecekleri basit seyleri seçmeye gayret ettim. Minimum malzemeyle maksimum sonuclar elde edilecek etkinlikler seçmeye çalsşım. ... 5 günün planım yapıyordum ber güne oyun, sanat, konu anlatımı, Türkçedil etkinliği ayarlyyordum. Bu etkinlikleri hafta içi okulun başlama saatinde göndermeye çalssyyordum. Cocuklara da velilere de mümkün olduğu kadar okul saatinde göndermeye çalşstım... Nasil okulda bir disiplin varsa evde de onu uygulamaya çalsștim. Herkes saatinde etkinliklere gelecek ve berkes bunu yapacak bunu yapmalarm istedim. Öğrencilik kavramın devam ettirmeye çalıștım.

Öğretmen 1'in pandemi sürecinde eğitim koşullarındaki değişikliklere ayak uydurmak için planlamalar yaptığı ve bir öğretmen olarak aktif bir biçimde sürece dahil olduğu ancak bu şekilde eğitim etkinliklerini yürütmenin güçlüklerine de vurgu yaptığ1 görülmektedir. Bazı öğretmenlerin ise hazır plan etkinlikleri ile birlikte bazen kendi etkinlik videolarını paylaşmak suretiyle aktif öğretmen davranışını sergiledikleri anlaşılmaktadır. Bu kapsamda Öğretmen 6 bazı etkinlikleri kendisinin yer aldığ1 videolar şeklinde planlayarak öğrencileri ile paylaştığından söz etmiştir. “Baそְ şeyleri video çekerek anlattım öğrencilerime. Videoya çekerken alş̧ı değilsin, heyecanlanyyorsun. Okuldaki rahat ortam olmuyor. Orada biraz, stres oluyordum.” Ayrıca Öğretmen 11 “Kendi etkinlik ve bikâye videolarm da paylaştım. Kendimi iyi hissetmedim. Zor oldu. Defalarca deneme çekimi yaptım” ve Öğretmen 30'da "Hikâye okurken, bilmece sorarken, șarkı söylerken video çekip veli grubuma koydum. Annem çektiği için anneme teşek.kür ettiler. İse yaradığgm düş̈̈ndüm. Bir yandan da birisi ile paylaşılarsa diye çekindim” şeklindeki ifadeleri bu durumu örneklendirmektedir. Öğretmenlerin ifadelerindeki "iyi hissetmedim, zor, rahat ortam olmuyor, başkea yerde paylaşırlarsa diye korktum” şeklindeki ayrıntılar kayg1, hazır bulunuşluk ve özgüven durumlarının öğretmenlerin uzaktan eğitim sürecine aktif olarak katılımlarını güçleştirdiğini göstermektedir.

Süreçte aktif olmayan öğretmenler ise hazır etkinlik planlarını, dijital eğitim materyallerini (yapboz ve hikâye kitabı gibi) ve çeşitli etkinlik linklerini velilere çocuğuyla birlikte evde yapmaları için “ileten” olmuşlardır. Bu davranışı benimseyen katılımcı öğretmenler, haftalık hazır planlarını velileriyle WhatsApp sınıf grupları aracıllı̆̆ıla paylaştıklarını belirtmişlerdir. Örneğin, Öğretmen 10, “Günlük etkinlikleri Whats App üzerinden paylașip dönüt bekleyerek gerçekleștirdim” ifadesiyle iletmiş olduğu etkinliklerin evde veliler tarafindan uygulamasını beklediğini ortaya koymuştur. Benzer şekilde, Öğretmen 22 WhatsApp üzerinden çeşitli sesli/görüntülü hikayeler, okuma yazmaya 
hazırlık çalışmaları, aile ile yapılabilecek sanat etkinlikleri, şarkılar ve oyunlar attım.” ifadeleriyle pandemi sürecinde eğitim etkinliklerinde aktif rol almadığını göstermiştir.

Uzaktan eğitim sürecinde öğretmen-yönetici ilişkilerinin farklılaştığ1 saptanmıştır. Katılımc1 öğretmenlerden bazıları yöneticilerinin rolünü Milli Eğitim Müdürlükleri tarafindan gönderilen yazışmaları kendilerine ileten olarak ifade etmiştir. Öğretmen 21'in bu bağlamdaki ifadesi şu şekildedir: "Yöneticimiz̨in bu süreşte uzaktan eğitimle alakah herbangi bir rolü yoktu. Sadece okula Milli Eğitimden gelen yažlar ya da 23 Nisanla ilgili yapmamız gerekenlerle ilgili gruptan bir seyler paylasstı. Onun dişında herhangi bir etkinliği olmadı.” İlköğretim bünyesinde bulunan anasınıflarında görev yapan katılımc1 öğretmenler kurum yöneticilerinin bu süreçte kendileri ile iletişime geçmediğini, herhangi bir toplantı düzenlemediğini belirtmişlerdir. Öğretmen 2, "İdare açıkçası ilkokulu ön planda tuttu. İdare bize yani ana sinfina yabancı. İdareyi daha çok biæyönlendirdik" ifadeleri ile pandemi sürecinde uzaktan eğitimi nasıl yapacaklarına dair yöneticilerden gerekli desteği almadıklarını dile getirmişlerdir. Öte yandan, bağımsız anaokullarında görev yapan katılımcı öğretmenler yöneticilerin kendileri ile etkileşim içinde olduklarını birlikte süreci etkileşerek yürüttüklerini söylemişlerdir. Çeşitli çevrimiçi toplantılar yapıldığını ve bu toplantılarda veli ile iletişimin devam ettirilmesi, velilerin EBA'yı kullanmaya yönlendirilmesi, çocuklardan alınan etkinlik dönütlerin (fotoğraf, video gibi) okul sosyal medya hesaplarından paylaşılması, çevrimiçi etkinliklerin planlanması, etkinlik planlarının sosyal medya hesabı üzerinden velilere evde yapmaları amacıyla gönderilmesi gibi çeşitli konularının konuşulduğunu belirtmişlerdir. Öğretmen 25, pandemi sürecinde okul yönetimi ile olan ilişkilerini aşağıdaki şekilde açıklamıştır.

Bu süreçte eğitim ögretim etkinliklerini haftahk bültenler șeklinde planlamak için yöneticilerim ve meslektaşlarmla online toplantılar gerçekleștirdik. Bu toplantılarda çocuklar için baftallk etkinlik. bültenleri planlama, velilere ve ögrencilere psikolojik anlamda destek olma, canle dersler planlama ve derslerin içeriği hakek.ndaki konularda konustuk.

Yukarıdaki ifadeler bazı okul yöneticilerinin öğretmenlerle eğitim etkinliklerinin yürütülmesi ve dönütlerin değerlendirilmesi ile ilgili fikir alış verişinde bulunduğunu ve rehberlik ettiğini, bir grup yöneticinin ise sürecin dışında kaldığı ve eğitim etkinliklerini öğretmenlerin inisiyatifine bıraktığ1 anlaşılmaktadır. Bu tarz yönetimin öz düzenlenme veya teknoloji kullanma becerisi sınırlı olan öğretmenler için dezavantaj oluşturduğu saptanmıştır.

Pandemi sürecinde öğretmenlerin velilerle olan etkileşim deneyimleri farklılaşmış, velilerle etkileşimde sosyal medya üzerinden eğitim kapsamında iletiler göndermek ve iletideki içeriğin uygulandığını gösteren dönütler (fotoğraf, video vb) beklemek ön plana çıkmıştır. Öğretmen 13’ün "Velilerle Whats App üzerinden iletișim kurduk. Haftalı, planlar gönderdim ve her gün uyguladıklar plânlarn 
resimlerini göndermelerini istedim. Uygulamayanlara ve uygulamak istemeyenlere ulasmak zor oldu" ifadeleri süreçteki etkileşim biçimini ortaya koymaktadır. Katılımcı öğretmenler ailelerin düşük sosyoekonomik düzeyde olmaları, teknolojik cihazlara ve internet erişimine sahip olmamaları, okul öncesi eğitimi önemsememeleri, çok çocuklu olmaları, ev dışında bir işte çalışmak durumunda kalmaları gibi nedenlerle etkinlikleri evde uygulama ve dönüt vermede sıkıntı yaşadıklarını belirtmiştir. Bu durumu Öğretmen 7’nin “Biz̧im okul öncesi ögretmeni olarak velisiž bir iş yapamadiğgmı zaten ortada biliyorsunu₹: Velinin desteği olmadan çocuklar okuma yąma bilmedikleri için, kendi özgürlüklerini kazanmadıklar için hiçbir şekilde hiçbir şey yapamyyoruz. Ulaşmak istesek çocuğa ulaşamyyoruz bile. Veli

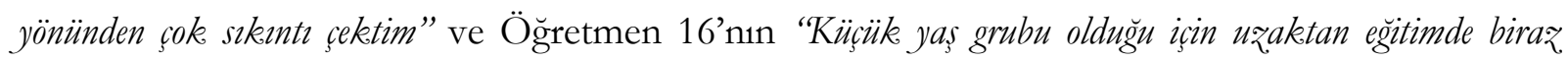
zorlandim veliler ağabeylerin, ablalarn dersleri ile ilgilendikleri için okul öncesi ögrencilerini biraz ibmal ettiler" ifadeleri ile ortaya koymuş ve pandemi sürecindeki bu yeni etkileşim biçiminde velilere yeterince ulaşamadıklarını ve bekledikleri dönütleri alamadıklarını belirtmişlerdir.

Pandemi sürecinde öğretmenlerin çocuklarla etkileşimlerindeki deneyimler de farklılaşmıştır. Bu süreçte öğretmenler dolaylı ve doğrudan etkileşim olarak tanımlanan iki farklı tarzda çocuklarla etkileşimlerini sürdürmüşlerdir. Dolaylı etkileşim kapsamında öğretmenler çocuklara ulaşmak için sadece ailelere etkinlik göndermiş ve aileleri arayarak çocukla ilgili bilgi paylaşımında bulunduklarını belirtmişlerdir. Dolaylı etkileşim kuran öğretmenlerden biri olan Öğretmen 14 çocuklarla olan etkileşimini "arayarak ve velilerle bireysel görüserek"; Öğretmen 21 ise "Cocuklarm bazılarmmn interneti telefonu olmadĭ̆ için veya bir kısmı köyde olduğu için birebir iletişsim kurmadım. Velilerin büyük çoğunluğuyla telefonda görïştüm" ifadeleri ile aileleri aracıllğıyla dolaylı olarak çocuklarla iletişim kurduğunu belirtmiştir. Katılımcı öğretmenlerin büyük bölümü ise çocuklarla doğrudan etkileşim kurduğunu; bunu çocuğu bireysel olarak sesli veya görüntülü arayarak, canlı video toplantıları yaparak gerçekleştirdiklerini belirtmişlerdir. Öğretmen 23 "Kesinlikle kurdum, düzenli olarak WhatsApp ve EBA ų̈̌erinden gönderdiğim çalışmalarla bilgilendirdim ve takibini yaptım, ZOOM, Hangouts gibi uygulamalarla canlı görü̈smeler yaptım. Simifin çoğunluğunun katılımın sağladım” sözleriyle pandemi sürecinde sınıfindaki çocuklarla etkileşimini koparmadığını vurgulamıştır. Ayrıca, Öğretmen 8 ise "Genelde özlem videolarnda kendimi çektim. Snapchat'in o filtrelerini çok uyguladım onu çok sevdiler. Tavşanl iște köpekli, sizi çok özledim diye videolar çektim gönderdim onlarla çok mutlu oldular eğlendiler" diyerek çocuklarla olan iletişiminin eğlenceli olmasına ve kendi sevgisini çocuklarla paylaşmaya özen gösterdiğini vurgulamıştır.

\section{Pandemi yönetici olmak}

Katılımcı yöneticiler pandemi sürecinde yaşadıklarını olumlu ve olumsuz yönleri olan farklı bir deneyim olarak tanımlamışlardır. Yöneticiler kendine ve ailesine zaman ayırma, çeşitli online 
eğitimlere katılma ve meslektaşlarla paylaşımın artmasını pandemi sürecindeki olumlu deneyimler olarak ifade etmişlerdir. Yönetici 3 "Yoğun bir çalışma tempomuz vard. Doğrnyu söylemek gerekirse bir es vermek beni çok mutlu etti. Kendime ve aileme zaman ayrmak, vakit geçirmek, uzaktan seminerlere ve kursa katılmak da güzeld?" sözleriyle olumlu deneyimlerini ortaya koymuştur. Yine katıllmc1 yöneticiler pandeminin hizmet içi eğitim adına oldukça verimli dönem olduğunu vurgulamışlardır. Örneğin Yönetici 2 sürecin kendisinin ve kurumundaki öğretmenlerin mesleki gelişimine katkısı olduğunu aşağıdaki ifadeleri ile ortaya koymuştur.

EBA üzerinden yine E-twinning üzerinden online eğitimlere katıldım. Mesela erken çocukluk daire başkanlĭğmn okul öncesi yönetici ve ögrretmenleriyle ilgili online eğitimlerine katuldım. Evde durunca da bu tip eğitimlere katılmış oldum...

Çevrimiçi yönetim ve denetim sorunları ile yalıtılmışlı/k/motivasyon düşüklügü ise yönetici olarak yaşanan olumsuz deneyimlerdir. Yöneticiler pandemi sürecinde en temel görevleri arasında yer alan öğretmenlerin ve çocukların eğitim etkinliklerini takip etme rollerinin sınırlandığını belirtmişlerdir.

Yöneticilik bu süreçte zordu. Çocuklarla biz, online olarak görïş̧mediğimiz için onlardaki ögretmenlerin etkisini göremedik. Cocuklarn gelişimini biz. göremedik... Bu sürecin etkisini ancak bize ögretmenlerimizin aktarmyyla ya da paylaşımlar varsa yaptıklarn görüsmelerden onlarla anlayabiliyoru₹. Dolayısiyla, bu konuda idareci olmak sılkintıl, yani ögretmen siže ne kadar yansitursa o kadarm bilebiliyorsunuz,

Yönetim, denetim ve personel işleri yöneticilerin çeşitli görevleri kapsayan bir görev tanımları arasındadır (MEB, 2014). Pandemi sürecinde eğitim öğretim etkinliklerini ve öğretmenlerin performanslarını doğrudan denetleme olanakları olmamıştır. Yöneticiler öğretmenlerin kendi geri bildirimleri ve EBA'ya giriş oranları üzerinden denetlemek durumunda kalmışlardır. Ayrıca öğretmen ve öğrencileri doğrudan gözlemleyememe, yüz yüze iletişim kuramamalarının yöneticilik algıırını olumsuz etkilediği anlaşılmaktadır. Şakayla karışık bir ifadeyle Yönetici 2, “E yani yönetici miyim değil miyim anlamadım. Öğretmenler ve ögrenciler olmaynca yönetici olduğunuðun farkında olamiyorsunu: Sadece okula gidip bina ile içli dışl oluyoru乏”" ifadesi pandemi sürecinde insan kaynaklarının (öğretmen, öğrenci) yokluğunun yöneticilik algısını olumsuz etkilediğini göstermektedir. Benzer şekilde, Yönetici 3 'Kendi kendimize kaldık...Whats App'tan attıklarmıฉa ve maillerimize dönmediler. Öğretmenlerin ne yaptıklarm ancak EBA raporlarndan takip edebildik." Katılımc1 yöneticiler bazı öğretmenlerin yeni oluşan uzaktan eğitim sürecine uyum sağlamadıklarını ve bu yönde çaba harcamadıklarını ifade etmişlerdir. Bu durumdan yakınan Yönetici 3 yaşadığı olumsuzlukları dile getirmiştir.

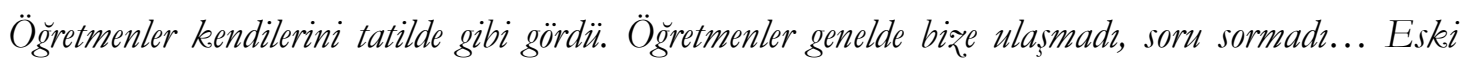
ögretmenleri yönlendirmek zor. Yeni ögretmenler gelişime yönlendirmeye daha açı. Eskiler yapmak 
istemiyorlar. Link atzyorsun ögretmen linki açyor ama nasil ilerleyeceğini bilemiyor. Aslinda biraz oturup karrstrursa yapacak... Biraz. ögretmenin istemesi önemli..

Katılımcı yöneticilerin tümü okullarında görev yapan bazı öğretmenlerin eğitim ve öğretimle ilgili sorumluluklarını tam anlamıyla yerine getirmediğini ve bu öğretmenlere rehberlik ve denetimde zorlandıklarını dile getirmişlerdir. Yönetici 8 ,"iki ögrretmenimiz, çok hassas davrand, diğer üç ögretmenimiz. ise ögrencilerin ĕgitimini umursamad. Velilerimiz̨den okulu arayanlar oldu diğer ögretmen etkinlik gönderiyormus biz̧im ögretmenimiそ göndermiyor diye” sözleriyle süreçte öğretmenleri denetleyemediklerini açıça ortaya koymuşlardır.

\section{Uzaktan eğitim vizyonu}

Bu çalışmadaki öğretmenlerin ve yöneticilerin yaşadıkları deneyimler temelinde genel olarak okul öncesi eğitimde uzaktan eğitimin etkili ve yeterli olmadığı konusunda hem fikir oldukları saptanmıştır. Pandemi sürecinin, uzaktan eğitim katılımcılarının büyük bir kısmında kayg1 yarattı̆̆1 ve okul öncesi eğitimde uzaktan eğitimin devam etmesi durumunda yapabilecekleri ile ilgili somut fikirlerinin olmadığ1 ve erken çocuklukta uzaktan eğitime ilişkin bir vizyon geliştiremedikleri anlaşılmaktadır. Örneğin Yönetici 8, “Açıkçası çok farkh ve stresli bir süreşti. Okul öncesi dönemde u₹aktan eğitim havada kalan bir mev₹u. Ben ve diğer yönetici ve ögretmen arkadaşlarm ayn fikirdeler. Okulöncesi eğitimin uzaktan eğitime dabil edilmemesi gerektiŭgi kanaatindeyim. Kald ki Eylül ayyla birlikte ilk defa okula gelen çocuklar, ilk defa ögretmen görecek çocuklar nasul dabil edilebilir uąktan eğitime? 1 ay ağlayan okula alışmakta zorluk çeken ögrencilerimiz, oldu. Yeni eğitim ögrretim ynlinda okul öncesi ve 1.smiflar uzaktan eğitime dabil edilmemeli." ifadeleriyle okul öncesi eğitim alanında uzaktan eğitimin olmaması gerektiğini net bir biçimde dile getirmiştir. Yönetici 8 erken çocukluk eğitiminin yüz yüze eğitim dışında bir alternatifi olmadığını düşünmekte ve gelişimsel olarak kritik dönemde olan çocukların eğitimden mahrum kalmamaları adına bir vizyon ortaya koyamamaktadır. Bu görüsslere paralel olarak Öğretmen 1 ve Öğretmen 3 ise aşağıdaki ifadeleriyle öğretmenlerin ve çocukların özelliklerinin uzaktan eğitim sürecinin etkililiğinin önünde engel teşkil ettiğini belirtmişler ve gelecekte uzaktan eğitim için öngörüde bulunamamışlardır.

Zor çok zor. Bence yetersiz. Okul öncesi dönemde olmaz. Ben açıkgası elimden geleni yaptım. Ama bą̌ arkadaslarm haz̧r planlar, kendi grubuna uygun olup olmadĭğm dabi düşünmeden, planlarm velilerine attı... O yüzden uzaktan eğitim sağhkll değil (Öğretmen 1); Neler yapabileceğimi gerçekten düsündüm. Beynim bu konuda ileriye adım atamyyor. Çünkü bu süreşte çocuklarla bire bir iletisimim olduğu balde cok zorlandik... Cok imkansiza yakin (Ögrretmen 3).

Öte yandan, bir kısım öğretmen ve yöneticilerin yaşadıkları deneyimler temelinde okul öncesi eğitimde uzaktan eğitimin geleceğine yönelik üç ana öneri içeren bir vizyon ortaya koydukları 
belirlenmiştir. Bunlardan ilki; çocukların uzaktan eğitim erişimini sağlamak için başta internet bağlantılarının, materyal ve platformlarının etkili kullanılmasıdır. "Baz̨ ailelerin evinde bilgisayar yok, telefon olmayan aileler var, ya da akıllh telefonu olup da görüntülü görüsme sağlayamayacak aileler de var" sözleriyle Yönetici 1 çocukların tamamının uzaktan eğitime erişemediğini belirtirken, Öğretmen 18 ise "EBA ya herkesin erişimi yok. Bir de EBA'yı kullanmada öncelik varsa abide ablada oluyor. Anasinufi çocuğu hep arkadan geliyor. Bağlanma sorunlar yaşanınca da aman tamam kalvversin oluyor” Bu durumlara çözüm olarak Öğretmen 21, "Mümkünse 2. el de olsa bilgisayar tablet temin etmek laẓm” derken, Öğretmen 1 "Susam Sokağ̀ formatında bir çocuk programı hą̧rlanabilir. Çünkü onda da kavramlar, sosyal hayat, okumaya geçis gibi bölümler vard. İsteyen kaçırdiğ bölïmü yeniden iəleyebilir” önerisi ile en azından internet bağlantısı olmayan veya EBA program saatlerine uygun olmayan çocuklar için alternatifler geliştirilebileceğini vurgulamıştır. İlave olarak katılımcı öğretmenlerin büyük bir bölümü, Eylül'de okullar açılmazsa veya kısıtlı olarak açılırsa, bu deneyimlerinden yararlanarak canlı etkinlikleri daha sık ve düzenli yapacaklarını, kendileri etkinliklerini video ile kaydederek YouTube gibi platformlarda yayınlayacaklarını ifade etmişlerdir. Örneğin Öğretmen 25,

Yeni dönemde u₹aktan eğitimin devam etme olasiliğnna karşı biraz bu dönemden tecrübe kazandiğım düşünüyorum. Yaptiğımın canl derslerin sayısın ve içeriğinin kapsamm arttırrm. Kavramlar daha

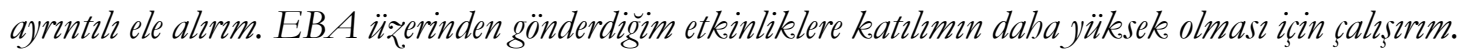

Yönetici 1 ise uzaktan eğitimin gelecek dönemde uygulanması durumunda "özellikle çocuk eğitimi, çocuk eğitiminde yapılan hatalar, çocuklara beceri kazandırma gibi anne-baba eğitimine yönelike programlar yapılabilir" ifadeleriyle ebeveynlerin uzaktan eğitim sürecinde aktif rol oynamalarının verimli bir eğitim için önemli olduğunu belirtmiştir. Çocuklara yönelik olarak Öğretmen 23, "Uq̧aktan eğitimle akademik olarak oldukeşa yoğun ve güzel çalısmalar yapıld. Ama sosyal duygusal ve büyük motor beceriler için yapılan çalıs̆malar yeterli olamadı, bu yüzden de yeni dönem başlangıconda bu çalıs̆malara ağırllk verilmesi uygun olacak" ifadeleri ile kendi vizyonunu ortaya koymuştur.

İkinci olarak öğretmenlerin teknoloji ve uzaktan eğitim yeterliliklerini artırmasının yararlı olacağını belirtirken bazı öğretmen ve yöneticiler bu konuda çeşitli hizmet içi eğitimlere katılarak yeterliliklerini artırma için adım atmışlardır. Farklı olarak, Öğretmen 15 uzaktan eğitim sürecinde en azından öğretmenler için çalışmalarını okulda yapmalarının yararlı olacağını aşağıdaki şekilde vurgulamıştır.

Benim de kendimi gelişstirerek ilerlemem görüntülü ve sesli paylaşım konusunda farkh orïinal fikirlere ulaşmam gerektiğini düsünüyorum. Ayrnca okullarmmə̨a ögretmenlerin bilgisayar, internet ve diğer teknolojileri kullanabilecekleri bir oda ayarlanabilir.

Üçüncü olarak katıllımc1 yönetici ve öğretmenlerin uzaktan eğitimin yüz yüze eğitime destek olarak pandemi geçtikten sonra kullanılmasının kaçınılmaz olduğunu vurgulamışlardır. Örneğin Öğretmen 
28, "Belki yüz yü̈re eğitim yannda uqaktan eğitim destekleyici olarak kullanulabilir" ifadesiyle uzaktan eğitimin destekleyici olarak devam edebileceğini belirtmektedir.

\section{SONUÇ VE TARTIŞMA}

$\mathrm{Bu}$ araştırma pandemi sürecinde öğretmen ve yöneticilerin eğitim deneyimlerine 1şık tutmuştur. Araştırmanın sonuçları dört önemli bulguyu ortaya koymaktadır. Bunlardan ilkine göre katılımcılar COVID-19’u bilimsel olarak tanımlamakla birlikte COVID-19 pandemisine ilişkin deneyimlerini "görünmeyen düşman, sinsi, imtihan, insanllğa verilen ders" gibi duygusal durumlarını ön plana çıkararak açıklamışlar ve pandemiyi "rahatlama-aşırı kayg1" şeklinde birbiriyle yer değiştiren zıt duygular şeklinde deneyimlemişlerdir. Bireyler COVID-19 sürecindeki bireysel ve kamusal alandaki çeşitli değişikliklere uyum sağlamak durumunda kalmıslardır. Bu durum pandemiye bireyleri psikolojik olarak da etkileme potansiyeli atfetmektedir (Aşkın, Bozkurt ve Zeybek, 2020). Bu çalışmadaki katılımcılar yaşadıkları duygusal ve düşünsel belirsizlikten duydukları rahatsızlığı oratya koymuşlardır. Bu durum pandeminin psikolojik etkisine işaret etmektedir. Bu bağlamda erken çocukluk alanındaki öğretmen ve yöneticilerin psikolojik iyi oluşlarını destekleyici çalışmaların yapılmasının mesleklerini etkili bir biçimde yürütmelerine, velilere ve çocuklara doğru rehberlik etmelerine katkı sağlayacağı düşünülmektedir. Araştırmalar psikososyal becerileri destekleyici müdahalelerin öğretmenlerin afetlerden kaynaklı streslerini azalttığını göstermektedir (Seyle, Widyatmoko ve Silver, 2013).

Araştırmadan elde edilen ikinci bulgu öğretmenlerin uzaktan eğitim sürecindeki deneyimlerini örgün eğitim için geçerli olan bilgi ve becerileri ile anlamlandırmaları ve eğitim etkinliklerini yeni sürecin unsurlanna göre düzenleyemediklerini göstermektedir. Uzaktan eğitim sürecinde ailelerle deneyimlenen sosyal medya ve sesli/görüntülü iletissim teknolojileri odaklı yeni iletişim biçiminin katılımcı öğretmenlerin çocuklarla etkileşimini güçleştirdiği, eğitim etkinliklerini gerçekleştirme ve değerlendirmelerinin önünde engel oluşturduğu ön plana çıkmıştır. Bu durumun katılımc1 öğretmenlerin uzaktan eğitim sürecinde eğitim faaliyetlerinin doğrudan planlayan ya da uygulayan olmak yerine farklı kaynaklardan edindikleri günlük plan dosyalarını sosyal medya ağlarından ailelere ileten ve dönüt bekleyen rolünü üstlenmelerine yol açtığı anlaşılmaktadır. Pandemi sürecine ilişkin diğer araştırmalardan elde edilen bulgular bu araştırmadaki bulgularla paralellik göstermektedir (Çakın ve Külekçi Akyavuz, 2020; Koçoğlu, Ulu Kalın, Tekdal ve Yiğen, 2020). Araştırmalar öğretmenlerin olağan üstü koşullarda eğitim ortamı, içeriği ve yöntemleri konusundaki değişimlere ayak uydurmakta zorlandıklarını (Cheng, 2020) ve gerek öğretmenlerin gerekse okul yöneticilerinin uzaktan eğitim konusunda eğitime ihtiyaç duyduklarını (Samuelsson, Wagner ve Ødegaard, 2020; Fedina, Burmykina, Zvedza, Pikalova, Skudnev ve Voronin, 2017) göstermektedir. Ayrıca pandemi 
döneminde yapılan bazı araştırmalar öğretmenlerin uzaktan eğitim konusunda olumsuz tutuma sahip olduklarını göstermektedir (Moçoşoğlu ve Kaya, 2020). Bu durum eğitimin her koşulda sürdürülebilmesi için çeşitli reformlara ihtiyaç olduğunu ortaya koymaktadır (Bozkurt, 2020). Bu çalışmadan elde edilen bulgular da öğretmen ve yöneticilerin sürece uyum sağlamada zorluk yaşadıklarını ve uzaktan eğitimle ilgili bilgi gereksinimi içinde olduklarını göstermektedir. Bu bağlamda lisans eğitiminde ilgili derslerin içeriklerinin bu gereksinimi karşılayacak yönde geliştirilmesi ve çeşitli dersler veya seminerler aracıllğ̆ ile alanda çalışan öğretmen ve yöneticilere örgün eğitimin mümkün olmadığı durumlarda eğitimi sürdürebilme becerilerinin kazandırılmas1 önemli görülmektedir. Diğer yandan erken çocukluk çağındaki çocukların çevrim içi eğitim ortamlarından etkili bir şekilde yararlanmaları yetişkin (aile) rehberliği gerektirmektedir (Bozkurt, 2020). Velilere eğitimin sürdürülmesindeki rolleri ve uzaktan eğitim platformlarının kullanımı ile ilgili eğitimler verilmesi eğitime katılım ve desteklerinin artması noktasında önemli görülmektedir. Ayrıca uzaktan eğitim sürecinde çocukların tüm gelişim alanlarının evde ve çevrimiçi eğitim sürecinde desteklenmesi süreçten kaynaklı olası dezavantajları azaltacaktır.

Bu araştırmadan elde edilen üçüncü bulguya göre yöneticiler pandemi sürecini özel yaşantıları ve mesleki gelişimleri açısından olumlu algılarken mesleki konumları açısından olumsuz algılamakta ve pandemide yönetici olmayı "yalnızlaşma ve yetki kaybı" olarak betimlemektedirler. Ayrıca yöneticiler süreçte bazı öğretmenlerin uzaktan eğitimi tatil olarak algıladıklarını düşünmüş ve bu öğretmenlere ulaşmada sorun yaşadıklarını ön plana çıkarmışlardır. Bu bulgu bir yandan hayat boyu öğrenmenin önemine işaret etmekte, diğer yandan eğitim yönetiminde liderlik kavramını ön plana çıkarmaktadır. Bu bağlamda yöneticilerin ve öğretmenlerin kişisel ve mesleki gelişimine katkı sağlayacak bazı eğitim, kurs ve sertifika programlarının uzaktan eğitim şeklinde planlanması ve erken çocukluk alanında çalışan yöneticilere liderlik becerilerinin kazandırılması önemli görülmektedir.

Araştırmadan elde edilen dördüncü bulgu katılımcıların erken çocuklukta uzaktan eğitimin geleceğine ilişkin görüşlerini kapsamaktadır. Katılımcıların uzaktan eğitimin uzun vadede sürdürülebilir olmadığı konusunda hemfikir oldukları anlaşılmaktadır. Bununla birlikte bazı katılımcılar pandemi deneyimleri temelinde gelecekte tekrar uzaktan eğitim yapılma olasıllğına karşı ne yapılabileceği konusunda herhangi bir öngörüde bulunamamış ve uzaktan eğitime karşıt görüş belirtmiştir. Bazı yöneticiler ve öğretmenler süreçteki deneyimleri temelinde uzaktan eğitimin örgün eğitime destek olarak kullanılması, uzaktan eğitim platformlarının erişim ve içerik açısından zenginleştirilmesi ve öğretmenlerin teknoloji ve uzaktan eğitim yeterliliklerinin geliştirilmesi şeklinde uzaktan eğitim kapsamında üç farklı vizyon ortaya koymuşlardır. Sistemlerin gelişmesi, varlığını sürdürmesi ve başarılı olabilmesi için öngörüde bulunularak, geleceğe yönelik hazırlıkların 
yapılması önem taşımaktadır (Ertürk, 2020). Erken çocukluk eğitimi yöneticileri, öğretmenleri, alan uzmanları ve bakanlık düzeyindeki yetkililerin bir araya gelerek olağanüstü koşullarda erken çocukluk eğitiminin nasıl yürütüleceği konusunda vizyon geliştirmeleri sürdürülebilirlik ve erken çocukluk yaş grubundaki tüm çocukların eğitim hakkının sağlanması açısından önemli görülmektedir. Ayrıca, televizyon ve radyo gibi yaygın medya aracılı̆̆ı ile ulusal düzeyde uzaktan eğitim içeriğinin geliştirilmesi ve örgün eğitime destek olarak kullanılması önerilmektedir. Uzaktan eğitim sistemlerinin erişim, içerik, kalite ve güvenlik gibi pek çok öge açısından geliştirilmesi etkililiği arttıracaktır (Can, 2020). Uzaktan eğitim platformlarında erken çocukluk eğitimi ile ilgili içeriğin zenginleştirilmesi, öğretmenlerin platformdaki rolünün artırılması ve öğretmenlere bu platformları etkili kullanma becerilerin kazandırılması önem taşımaktadır. Pandemi sürecinde erken çocukluk eğitimi alanında çalışan öğretmenlerle gerçekleştirilen araştırmalarda öğretmenlerin teknoloji yeterliliklerinin desteklenmesine vurgu yaptıkları (Alan, 2021) anlaşılmaktadır. Farklı kademelerde öğretmenlerle gerçekleştirilen araştırmalar bu araştırma bulguları ile paralel olarak bazı öğretmenlerin uzaktan eğitim sürecini olumsuz, verimsiz, dönütü olmayan şeklinde olumsuz olarak algıladıklarını bazı öğretmenlerinse daha çok eğitimin sürdürülebilirliği için önemine odaklandıkları ve olumlu bir algı içerisinde oldukları anlaşılmaktadır (Kazu, Bahçeci ve Kurtoğlu Yalçın, 2021). Pandemi ve benzeri olağan üstü koşullarda erken çocukluk döneminde uzaktan eğitim uygulamalarının yüz yüze eğitim ve çevrim içi eğitimin bir arada yer aldığ1 model şeklinde planlanmasının veli, öğretmen, yönetici ve çocuklar açısından daha etkili sonuçlar doğuracağı düşünülmektedir. Diğger yandan çeşitli nedenlerle uzaktan eğitimden faydalanamayan çocuklara eğitim içeriğinin basılı materyaller aracılı̆̆ı ile ulaştırılması önem taşımaktadır.

Pandemi insan hakkı olan eğitimi küresel düzeyde kesintiye uğratan bir deneyim olmuştur. Ancak savaş, deprem, sel, kasırga gibi pek çok olağanüstü durum yerel düzeyde eğitimi kesintiye uğratabilmektedir. Bu nedenle bu tür durumlara hazırlıklı olmak ve eğitime katılımı güvence altına almak adına her düzeyde olduğu gibi erken çocukluk eğitimi kapsamında da planlamaların yapılması önem taşımaktadır. Bu planlama uzaktan eğitim programının hazırlanması, çocukların uzaktan eğitim deneyimi kazanması, öğretmenlerin ve velilerin uzaktan eğitim sürecine bilişsel ve duyuşsal olarak hazırlanması şeklinde yapılmalıdır.

Bu çalışmanın verileri ülkemizde pandemi ile bağlantılı önlemlerin alındığı ilk aylarda toplanmıştır. Bahar 2021 eğitim öğretim dönemi ile birlikte pandemi koşullarında 3 dönemlik bir eğitim süreci geride bırakılmıştır. Erken çocukluk eğitim kurumlarında tüm personeli kapsayan araştırmaların gerçekleştirilmesinin uzaktan eğitim sürecinin nasıl yönetildiği, etkili uygulamalar ve geliştirilmesi gereken yönler noktasında alan yazına ve uygulamalara katkı sağlayacağı düşünülmektedir. 
$\mathrm{Bu}$ çalışma bulguları yönetici ve öğretmenlerin kendi yaşadıkları güçlüklerle birlikte pandemi sürecinde çocukların erken çocukluk eğitimine katılımlarının sınırlı olduğunu da ortaya koymaktadır. Bu bağlamda erken çocukluk eğitim kurumlarının yüz yüze ve çevrim içi eğitime dahil olamayan çocukların aileleri ile birlikte katılabilecekleri küçük gurup etkinlikleri planlanması ve eğitim öğretim saat ve dönemleri dışında kurumda uygulamalarının önemli olduğu düşünülmektedir.

Pandemi dönemi geride bırakıldığında pandemi ile birlikte hızlı bir şekilde öğretmen ve yöneticilerin yaşamına giren mesleki gelişim, teknolojinin eğitim ve öğretime entegre edilmesi, eğitim öğretim etkinliklerinin planlanmasında ailelerle işbirliği gibi fırsatların gözden geçirilmesi ve pandemi ile eğitim personelinin yaşantısına giren bu fırsatların devam ettirilmesi ile ilişskili projelerin geliştirilmesi önemli görülmektedir.

\section{KAYNAKÇA}

Al, U., ve Madran, R.O. (2004). Web tabanlı uzaktan eğitim sistemleri: Sahip olması gereken Özellikler ve standartlar. Bilgi Dünyası, 5(2), 259-271.

Alan, Ü. (2021). Distance education during the covid-19 pandemic in turkey: 1dentifying the needs of early childhood educators. Early Childhood Education Journal, 1-8. http:/ /link.springer.com/article/10.1007/s10643-021-01197-y

Alisinanoğlu, F., Türksoy, E., Karabulut, R. (2020). Pandemi sürecinde çocukluk dönemi korkuları. Uluslararası Beşeri Bilimler ve Ë̈itim Dergisi, 6 (14), 447-568. Retrieved from https://dergipark.org.tr/en/pub/ijhe/issue/57645/782570

Aral, N., Fındık, E., Öz, S., Karataş, B. K., Güneş, L. C. \& Kadan, G. (2021). Covid 19 pandemi sürecinde okul öncesi dönemde uzaktan eğitim: deneysel bir çalışma. Turkish Studies Education, 16(2), 1105-1124. https://dx.doi.org/10.47423/TurkishStudies.49289

Asskın, R., Bozkurt, Y. ve Zeybek, Z. (2020). COVID-19 pandemisi: Psikolojik etkileri ve terapötik müdahaleleri. Istanbul Ticaret Üniversitesi Sosyal Bilimler Dergisi, Sosyal Bilimler Özel Sayısı, 19(37), 304-318.

Balaban, M.E. (2012). Dünyada ve Türkiye'de uzaktan eğitim ve bir proje önerisi. İstanbul: Işıle Üniversitesi. 20 Haziran 2020 tarihinde http://www.erdalbalaban.com/wpcontent/uploads/2012/12/UE_UzaktanEğitim_EB.pdf adresinden erişilmiştir.

Bozkurt, A. (2017). Türkiye'de uzaktan eğitimin dünü, bugünü ve yarını. $A U A d, 3(2), 85-124$.

Bozkurt, A. (2020). Koronavirüs (COVID-19) pandemi süreci ve pandemi sonrası dünyada eğitime yönelik değerlendirmeler: Yeni normal ve yeni eğitim paradigması. $A U A d, 6(3), 112-142$.

Bozkurt, A., Jung, I., Xiao, J., Vladimirschi, V., Schuwer, R., Egorov, G., Paskevicius, M. (2020). A global outlook to the interruption of education due to COVID-19 Pandemic: Navigating in a time of uncertainty and crisis. Asian Journal of Distance Education, 15(1), 1-126. https://doi.org/10.5281/zenodo.3878572

Bozkurt, A., ve Sharma, R. C. (2020). Emergency remote teaching in a time of global crisis due to CoronaVirus pandemic. Asian Journal of Distance Education, 15(1), i-vi. https://doi.org/10.5281/zenodo.3778083 
Can, E. (2020). Coronavirüs (COVID-19) pandemisi ve pedagojik yansımaları: Türkiye'de açık ve uzaktan eğitim uygulamaları. $A U A d, 6(2), 11-53$.

Cheng, Y. C. (2020, June). The futures of education after COVID-19: Multiple disruptions ve lessons [Webinar]. Paper presented at the Webinar \#4 (ENG/AR): The Futures of Education after COVID-19 - Arab Region Dialogue, France. Retrieved from https://en.unesco.org/futuresofeducation/webinars.

Creswell, J. W. (1998). Qualitative inquiry and research design: Choosing among five tradition. Thousand Oaks, CA: Sage

Creswell, J. W., Hanson, W. E., Clark Plano, V. L., ve Morales, A. (2007). Qualitative Research Designs: Selection and Implementation. The Counseling Psychologist, 35(2), 236264. https://doi.org/10.1177/0011000006287390

Cupit Swenson, C., Saylor, C. B., Powell, P ve Belter, R. (1996). Impact of a natural disaster on preschool children: Ajustment 14 months after hurricane. Americane Journal of Orthopsychiary. 66(1), 122-130.

Çakın, M., Külekçi Akyavuz, E. (2020). The COVID-19 process and its reflection on education: An analysis on teachers' opinions. International Journal of Social Sciences and Education Research, 6(2), 165-186.

Demir Öztürk, E., Kuru, G. ve Demir Yıldız, C. (2020). COVID-19 pandemi günlerinde anneler ne düşünür çocuklar ne ister? Anne ve çocuklarının pandemi algısı. Avrasya Sosyal ve Ekonomi Arastirmalar Dergisi, 7(5), 204-220.

Eğitim Bilişsim Ağı (2020). EBA Hakkında. Yenilik ve Eğitim Teknolojileri Genel Müdürlüğü. 11. 07. 2020 tarihinde http://www.eba.gov.tr/ adresinden erişilmiştir.

Ergünay, O. (2009). Afet yönetimi: Genel ilkeler, tanmlar ve kavramlar. Ankara: DSİ.

Ertürk, A. (2020). 2023 Eğitim Vizyonu: Sorunlara çare mi? Pamukkkale Üniversitesi Eğitim Fakültesi Dergisi,48, 321-345. doi: 10.9779/pauefd.537273.

Fedina, N.V., Burmykina, I.V., Zvedza, L.M., Pikalova, O.S., Skudnev, D.M. ve Voronin, I. V. (2017) Study of educator's and parent's readiness to implement distance learning technologies in preschool education in Russia. EURASLA Journal of Mathematics, Science and Technology Education, 13(12), 8415-8428.

Göl-Güven, M., Alvan, G., Erbil, F., Özgünlü, M., Şeker, V. ve Uzunkök, B. (2020, Temmuz). COVID-19 pandemisinin aile yaşantısına yansımaları (COVID-19 Aile) rapor-1. 27 Temmuz 2020 tarihinde https:/ / cocukbogazi.com adresinden erişilmiştir.

Halk Sağlığ1 (2020, Haziran). COVID-19 Genel Bilgiler, Epidemioloji ve Tan1. 22.08.2020 tarihinde https://www.tahud.org.tr/file/cdd0219d-4c17-4460-ade3-0b0aad742c0b/COVID-

19_REHBERI_GENEL_BILGILER_EPIDEMIYOLOJI_VE_TANI.pdf adresinden erişilmiştir.

Hassan, F.U., Singh G., Sekar, K. (2018). Children's reactions to flood disaster in Kashmir. Indian J Psychol Med. 40, 414-419.

Huberman, A.M., ve Miles, M.B. (1994). Data management and analysis methods. In N.K. Denzin \& Y.S. Lincoln (Eds.), Handbook of qualitative research (p.428-444). Sage Publications Inc.

Işıkoğlu Erdoğan, N . (2019). Dijital Oyun Popüler mi? Ebeveynlerin Çocukları İçin Oyun Tercihlerinin İncelenmesi. Pamukkale Üniversitesi Eğitim Fakültesi Dergisi, 46, 1-17 . DOI: $10.9779 /$ pauefd. 446654 
Karabulut, D., ve Bekler, T. (2019). Doğal afetlerin çocuklar ve ergenler üzerindeki etkileri. Doğal Afetler ve Cevre Dergisi, 5(2), 368-376.

Kazu, İ., Bahçeci, F., Kurtoğlu Yalçın, C. (2021). Öğretmenlerin koronavirüs pandemisi döneminde verdikleri uzaktan eğitime ilișkin metaforik algıları. Furat Üniversitesi Sosyal Bilimler Dergisi, 31 (2), 701-715. DOI: 10.18069/firatsbed.814015

Kim, J. (2020). Learning and teaching online during COVID-19: experiences of student teachers in an early childhood education practicum. IJEC (2020). https://doi.org/10.1007/s13158020-00272-6

Koçoğlu, E., Ulu Kalın, Ö., Tekdal, D. ve Yiğen, V. (2020). "COVID-19 Pandemi Sürecinde Türkiye'deki Eğitime Bakış” International Social Sciences Studies Journal, (e-ISSN:2587-1587), 6(65), 2956-2966

Konca, A.S., Ozel, E. ve Zelyurt, H. (2016). Attitudes of preschool teachers towards using information and communication technologies (ICT). International Journal of Research in Education and Science (IJRES), 2(1), 10-15.

Larkin, M., Watts, S. ve Clifton, E. (2006). Giving voice and making sense in interpretative phenomonological analysis. Qualitative Research in Psychology, 3(2), 102-120.

Manches, A., ve Plowman, L. (2017). Computing education in children's early years: A call for debate. British Journal of Educational Technology, 48(1), 191-201.

Mertala, P. (2019). Teachers' beliefs about technology integration in early childhood education: A meta-ethnographical synthesis of qualitative research. Computers in Human Behavior, 101, 334-349. https://doi.org/10.1016/j.chb.2019.08.003.

Milli Eğitim Bakanlığı, (2020). Uzaktan eğitim bakan Selçuk'un verdiği dersle başladı. [Basın Bülteni]. 23 Mart 2020 tarihinde http://www.meb.gov.tr/meb_haberindex.php?dil=tr adresinden erișilmiștir.

Moçoşoğlu, B. ve Kaya, A. (2020). Koronavirüs hastalığı (Covid-19) sebebiyle uygulanan uzaktan eğitime yönelik öğretmen tutumlarının incelenmesi. Kabramanmaraş Sütçü İmam Üniversitesi Ë̈itim Dergisi, 2(1), 15-43

OECD (2020). 2020 COVID-19 Pandemisine Karşı Eğitimde Atılabilecek Adımlara Rehberlik Edecek Bir Çerçeve. 7 Temmuz, 2020 tarihinde https://globaled.gse.harvard.edu/files/geii/files/framework_guide_v4_tr.pdf. adresinden erişilmiştir.

OMEP Executive Committee, World Organisation for Early Childhood Education (2020). OMEP Position Paper: Early Childhood Education and Care in the Time of COVID19. International Journal of Early Childhood, 1-10. Advance online publication. https://doi.org/10.1007/s13158-020-00273-5

Petriwskyj, A. (2013). Reflections on talk about natural disasters by early childhood educators and directors. Australian Journal of Communication, 40 (1). 87-100.

Prime, H., Browne, D. T., ve Wade, M. (2020). Risk and resilience in family well-being during the COVID- 19 pandemic. American Psychologist. 75(5), 631-643 http://dx.doi.org/10.1037/amp0000660631

Reggio Children (2021). At home with the Regio approach. 7 Temmuz 2021 tarihinde https://www.reggiochildren.it/en/athomewiththereggioapproach/ adresinden erişilmiştir.

Reimers, F. M. \& Schleicher, A. (2020). A framework to guide an education response to the COVID-19 Pandemic of 2020. 7 Temmuz 2021 tarihinde 
https://globaled.gse.harvard.edu/files/geii/files/framework_guide_v2.pdf adresinden erișilmiștir.

Samuelsson, I.P. • Wagner, J.T. ve Ødegaard, E.E. (2020). The coronavirus pandemic and lessons learned in preschools in Norway, Sweden and the United States: OMEP Policy Forum. International Journal of Early Childhood.52, 129-144. https://doi.org/10.1007/s13158-02000267-3

Seyle, D. C., Widyatmoko, C. S., ve Silver, R. C. (2013). Coping with natural disasters in Yogyakarta, Indonesia: A study of elementary school teachers. School Psychology International, 34(4), 387 404.

Smith, J. A., ve Osborn, M. (2004). Interpretative phenomenological analysis. In G. M. Breakwell (Ed.), Doing social psychology research (pp. 229-254). Leicester, England: British Psychological Society. https://doi.org/10.1002/9780470776278.ch10

Smith, J., Flowers, P., Larkin, M. (2009). Interpretive phenomenological analysis: Theory, method and research. Thousand Oaks, CA: Sage.

Stake, E. R. (1995). The art of case study research. Thousand Oak, CA: Sage.

Stock McIsaac, M. (2020). Distance learning. 27 Haziran 2020 tarihinde https://ocw.metu.edu.tr/file.php/118/Week10/Gunawardena-McIsaac-distance-ed.pdf. adresinden erişilmiştir.

Szente, J. (2016). Assisting children caught in disasters: resources andsuggestions for practitioners. Early Childhood Education Journal, 44, 201-207. DOI:10.1007/s10643-015-0709-2.

Tarkoçin, S., Alagöz, N. \& Boğa, E. (2020). Okul öncesi dönem çocuklarının pandemi sürecinde (COVID19) davranış değişiklikleri ve farkındalık düzeylerinin anne görüşlerine başvurularak incelenmesi. Turkish Studies, 15(6), 1017-1036. https://dx.doi.org/10.7827/TurkishStudies.44338

Tokić, I.S. ve Vukašinović, A. (2020). Continuity of educational process through virtual kindergarten during COVID-19 outbreak - case study from Croatia. Proceedings of EDULEARN20 Conference 6th-7th July 2020.

World Bank Group (2020). Three principles to support teacher effectiveness during COVID-19. $24 \quad$ Temmuz $2020 \quad$ tarihinde http://documents1.worldbank.org/curated/en/331951589903056125/ Three-Principlesto-Support-Teacher-Effectiveness-During-COVID-19.pdf adresinden erişilmiştir.

Yıldırım, A. ve Şimşek, H. (2013). Sosyal bilimlerde nitel araştırma yöntemleri. Ankara: Seçkin Yayıncılık.

Yilmaz, E., Mutlu, H., Güner, B., ve Doğanay, G. (2020). Veli algrsına göre pandemi süreci uحaktan eğitim sürecinin niteliği. Konya: Palet Yayınları. ISBN: 978-625-7057-34-9

Yoshikawa H, Wuermli A.J., Britto P.R., Dreyer B., Leckman J.F., Lye S.J., Ponguta L.A., Richter L.M., Stein A. (2020). Effects of the Global COVID-19 Pandemic on Early Childhood Development:Short- and Long-Term Risks and Mitigating Program and Policy Actions The Journal of Pediatrics. doi: https://doi.org/10.1016/j.jpeds.2020.05.020.

Yurt, Ö., ve Cevher-Kalburan, N. (2011). Early childhood teachers' thoughts and practices about the use of computers in early childhood education. Procedia Computer Science,3, 1562-1570. 